\title{
乳糖の結晶転移による固形化粉ミルクの硬度への影響
}

\author{
柴田満穂, ${ }^{*, a}$ 大坪和光, ${ }^{a}$ 大原三佳, ${ }^{b}$ 尾前里佳, ${ }^{b}$ 丹羽敏幸, ${ }^{b}$ 檀上和美 $b$
}

\section{Effect of Crystalline Metastasis of Lactose on Hardness of Compressed Baby Milk Powder}

\author{
Mitsuho Shibata, ${ }^{*, a}$ Kazumitsu Otsubo, ${ }^{a}$ Mika Ohara, ${ }^{b}$ \\ Rika Omae, ${ }^{b}$ Toshiyuki Niwa, ${ }^{b}$ and Kazumi Danjo ${ }^{b}$ \\ ${ }^{a}$ Production Technology \& Engineering Department, Food Technology Research Labs., R\&D Division, \\ Meiji Co., Ltd.; 540 Naruda, Odawara 250-0862, Japan: and ${ }^{b}$ Faculty of Pharmacy, \\ Meijo University; 150 Yagotoyama, Tenpaku-ku, Nagoya 468-8503, Japan.
}

(Received July 9, 2012; Accepted August 20, 2012)

The purpose of this study was to examine the relationship between the crystalline metastasis of lactose, which is a main component baby milk powder, and the hardness of baby milk powder compressed by humidification followed by drying. Because baby milk powder is manufactured using a spray dryer, lactose in compressed baby milk powder exists in an amorphous (solid dispersion) form. X-ray diffraction measurement showed that this amorphous lactose metastasized to $\beta$-form crystalline lactose, and thereafter metastasized to the $\alpha$-form during the humidification-drying process. As a result of this crystalline metastasis, the hardness of the compressed baby milk powder increased, and then decreased. Furthermore, scanning electron microscopy (SEM) showed bridging structures between the particles increased and then decreased during the humidification-drying process. This showed that bridging structures between the particles produced by crystalline metastasis of lactose as a result of the humidification-drying process, which leads to an increase in the hardness of the compressed baby milk powder. These results show that the necessary degree of hardness of the porous compressed baby milk powder (necessary for packaging and transportation) resulted from the humidification-drying process.

Key words_ compressed baby milk powder; crystalline metastasis; hardness; crystalline lactose; amorphous; humidification

緒 言

医薬品の分野では，口腔内崩壊錠を調製する際に 糖類を用いることが多い。非晶質糖類は成形性がよ くロ腔内において速やかに崩壊する特性を有するも のがあり，口腔内崩壊錠の設計にはよく用いられ る. 結晶性の糖と非晶質の糖を混合して圧縮成形し て吸湿乾燥を行うと, 非晶質糖が結晶化することに より錠剂強度が増し, 崩壊性もよいものが得られる 報告がある. ${ }^{1-3)}$ 小島ら ${ }^{4)}$ は, 非晶質マルトースとマ ンニトールを混合して加湿処理すると非晶質マル トースが結晶化して圧縮成形成がよくなることを報 告している.

The authors declare no conflict of interest. $a$ 株式会社明治技術開発研究所, $b$ 名城大学薬学部 *e-mail: mitsuho.shibata@meiji.com
本研究で用いた乳児用調製粉乳（粉ミルク）は顆 粒状のものが主流であったが，近年，付加価值を高 めた固形化粉ミルクの製造法が注目されている. 固 形化粉ミルクの製造法としては，粉ミルクを低圧圧 縮力で成型した後, 加湿及び乾燥して表面のみを硬 化する方法5-8)である。この方法により製した錠剤 型粉ミルクは, 輸送等の衝撃には耐え, 使用する際 に容易に溶解し，素早く幼児に飲ませることができ る.

先に筆者らは，錠剤型粉ミルクの物性について， 特に錠剂の硬度は吸湿と乾燥により粒子間において 固体架橋の増加が起こり，錠剤硬度が増大したこと を報告9)した。しかし，錠剤強度の増大の元となる 固体架橋が何に起因するかについては，報告するこ とができなかった，そこで，今回は固体架橋の原因 となる因子の解明と錠剂硬度の関係について有益な 
知見が得られたので報告する.

\section{実 験 方 法}

1. 試料噴霧乾燥法により製造された市販の 粉ミルクを使用した。この粉ミルクは顆粒状（平均 粒子径は約 $250 \mu \mathrm{m}$ ） であり，組成は脂肪 $25 \%$ ，夕 ンパク質 $11.7 \%$ ，炭水化物 $58.3 \%$ （このうち乳糖 $51 \%) ，$ ミラル $2.2 \%$ である。なお，粉ミルクの 他の添加剤は使用していない.

2. 試薬 $\alpha$ 乳糖一水和物（和光純薬工業製 試 薬特級), 及び, $\beta$ 乳糖無水物（関東化学製 試薬特 級）は市販品を使用した.

3. 結晶乳糖の定量用標準混合物の調製 粉乏 ルク，及び， $\alpha$ 乳糖一水和物（以降， $\alpha$ 乳糖）又は $\beta$ 乳糖無水物（以降， $\beta$ 乳糖）を Table 1 に示した 質量比で計りとり，ビーカー内でスパーテルを使用 して，粉を擦り潰さないように注意深く混合して標 準混合物を調製し，結晶の定量に対する検量線の作 成に用いた。

4. 粉ミルクの成形体の調製 圧縮成形性測定 装置（タブフレックス，岡田精工侏）を用い，直径 $20 \mathrm{~mm}$ の臼に粉ミルク約 $1.8 \mathrm{~g}$ を充填したのち, $3.2 \mathrm{MPa}$ で圧縮成形した。成形体を $97 \% \mathrm{RH}$ に調 湿したデシケーター中 $60^{\circ} \mathrm{C}$ に所定の時間静置して 加湿した。 その後, $60^{\circ} \mathrm{C}$ で 5 分間乾燥した。

5. 粉末 $\mathbf{X}$ 線回折による結晶性の測定 加湿 乾燥前後の成形体表面の結晶性を，粉末 $\mathrm{X}$ 線回折 装置 (Smart Lab，侏リガク）にて測定した。なお， 試料を回転させて測定ができる専用アタッチメント （ASC-6，诛侏リガク）を用いた。 X 線には $\mathrm{CuK} \alpha$, $\mathrm{Ni}$ フイルターを用い, 電圧 $30 \mathrm{kV}$, 電流 $20 \mathrm{~mA}$, 走查速度 $2 \% / \mathrm{min}$ の条件で回折強度を測定した。結 晶乳糖の定量では，ステップスキャン法（ステップ

Table 1. Composition of Phycal Mixture

\begin{tabular}{ccc}
\hline $\begin{array}{c}\text { Content of Crystal } \\
\text { Lactose [\%] }\end{array}$ & $\begin{array}{c}\text { Crystal Lactose } \\
{[\mathrm{g}]}\end{array}$ & $\begin{array}{c}\text { Milk Powder } \\
{[\mathrm{g}]}\end{array}$ \\
\hline 5 & 2.5 & 47.5 \\
10 & 5 & 45 \\
20 & 10 & 40 \\
40 & 20 & 30 \\
50 & 25 & 25 \\
60 & 30 & 20 \\
\hline
\end{tabular}

間隔 $0.02^{\circ}$ ）にて得た回折パターンを，平滑化とバ ックグラウンド除去処理してピーク面積を求めた.

6. 錠剂硬度試験 錠剂硬度計（PC-30, 岡田 精工侏）を用い，成形体 5 個について破断試験を行 った.

7. 走査型電子顕微鏡 (scanning electron microscope；SEM）加湿乾燥前後の錠剤をオートファ インコータ（JFC-1600，日本電子秼）により，30 $\mathrm{mA}, 90$ 秒の条件で白金コーティング処理した。そ の後, SEM (JSM-6060, 日本電子株) を使用して, 加速電圧 $7 \mathrm{kV}, 100$ 倍で観察した.

\section{結 果 と考察}

1. 成形体の加湿乾燥前後の結晶性 成形体の 加湿乾燥前後による結晶性の変化を Fig. 1 に示し た。粉ミルクは噴霧乾燥造粒法で調製された造粒品 であり，この造粒品を圧縮して得られた成形体も Fig. 1 b) に示したように, 結晶性が非常に小さく非 晶質に近いものであることを示唆した．一方，この 錠剂を加湿したのち乾燥させた場合，Fig. 1 a)に示 したように，加湿 1 時間後乾燥させると，多くの回 折ピークが観察され，結晶化していることが判明し た。すなわち，従来から報告10)されているように， 吸湿させて乾燥させることにより非結晶であったも のが結晶化することが明らかになった。

$\beta$ 乳糖，及び， $\alpha$ 乳糖の回折パターンを Fig. 2 に 示した. ともに $20^{\circ}$ 付近に複数の大きなピークと $10.5^{\circ} ， 12.5^{\circ}$ にそれぞれの結晶形で特徽的なピーク が観察された. Figure 1 で示した粉ミルクの加湿後 の成形体の回折パターンには, $10.5^{\circ}$ と $12.5^{\circ}$ にピー

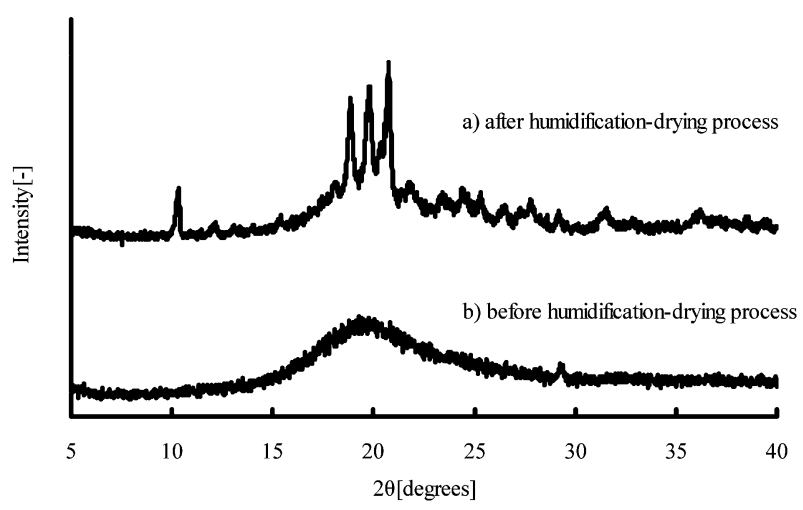

Fig. 1. Powder X-ray Diffraction Patterns of Compressed Baby Milk Powder 
クがみられたことから，加湿乾燥により $\beta$ 型結晶 乳糖無水物と $\alpha$ 型結晶乳糖一水和物が含まれてい ることがわかった。

2. 成形体表面中の結晶乳糖の定量 加湿乾燥 した成形体の粉末 X 線の回折パターン（平滑化と バックグランド処理済み）を Fig. 3 に例示した. これより， $10.5^{\circ}(\beta$ 乳糖に相当 $)$ と $12.5^{\circ}(\alpha$ 乳糖 に相当）のピークの面積が良好に測定できると考え られた. Figure 4 に結晶乳糖の配合量とのピーク面 積との関係を示した. $10.5^{\circ}$ と $12.5^{\circ}$ ともに結晶乳糖 の配合量とピーク面積との間に，ほぼ原点を通る直 線性が得られた。 以上より，既知濃度の結晶乳糖を 含んだ標準混合物と加湿乾燥した成形体の $10.5^{\circ}$, $12.5^{\circ}$ のピーク面積から，成形体表面中の結晶乳糖 の定量が可能であると考えられた。

3. 成形体の加湿乾燥による硬度の変化先に 筆者らは粉ミルクを圧縮成形した錠剂の加湿乾燥に よる錠剂硬度の変化について報告9)した。今回は, 成形体硬度に及ぼす加湿時間の影響について検討を

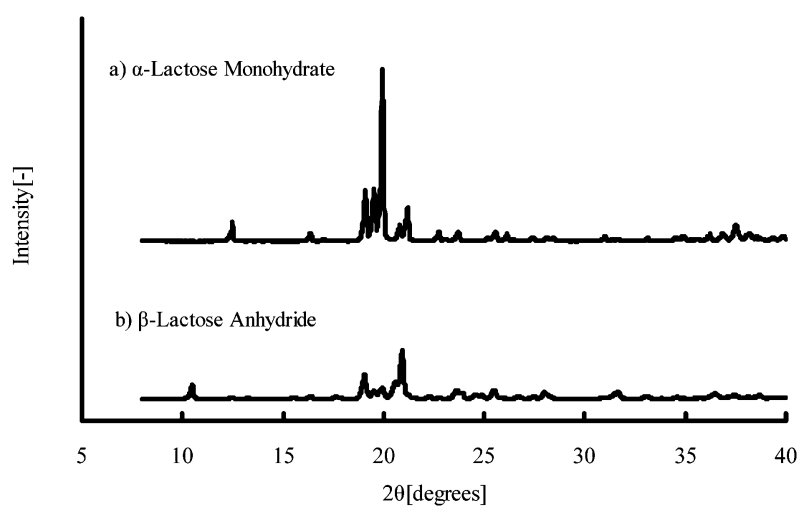

Fig. 2. Powder X-ray Diffraction Patterns of Crystal Lactose

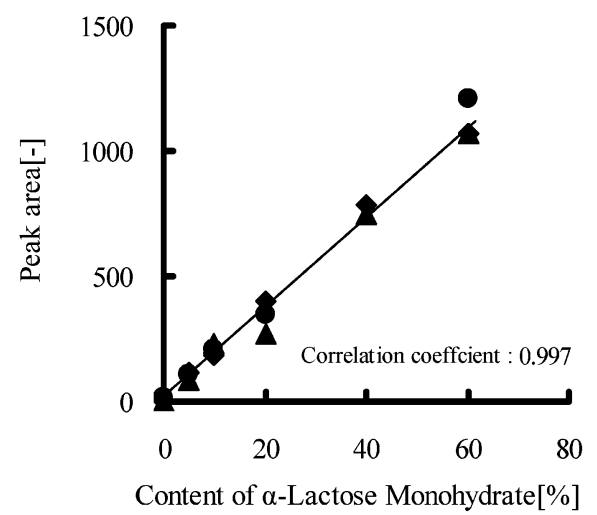

行うと同時に，粉ミルクの結晶転移との関連性につ いて調べた.

加湿時間と成形体の引張強度の関係を Fig. 5 に 示した。引張強度は加湿時間の増加に伴って増大 し，加湿が 1 時間において最大となり，その後，加 湿時間が長くなるにしたがい低下した.

成形体を加湿乾燥すると，粒子接触点において固 体架橋を形成することは前報9)で述べた。加湿時間 が異なる成形体表面の固体架橋の様子を SEM によ り観察して Fig. 6 に示した. 100 倍での観察結果か ら，加湿乾燥前の成形体表面の粒子間では隙間があ り，架橋はみられなかった。加湿 0.5 時間で，粒子 間の隙間は減少と架橋がみられ，加湿 2 時間でこの 傾向は強くなった．加湿 8 時間では，粒子同士の架 橋は減少し，粒子の形状が明瞭にみられた。固結に より粒子間で固体ブリッジを発生することで硬度が 増大することが知られている11)が，本報告において

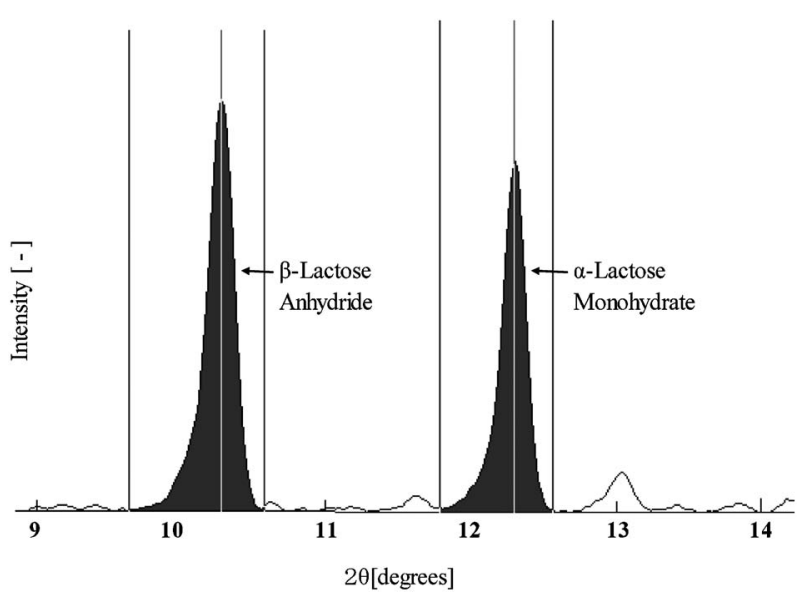

Fig. 3. Powder X-ray Diffraction Pattern of Compressed Baby Milk Powder for Calculating Peak Area

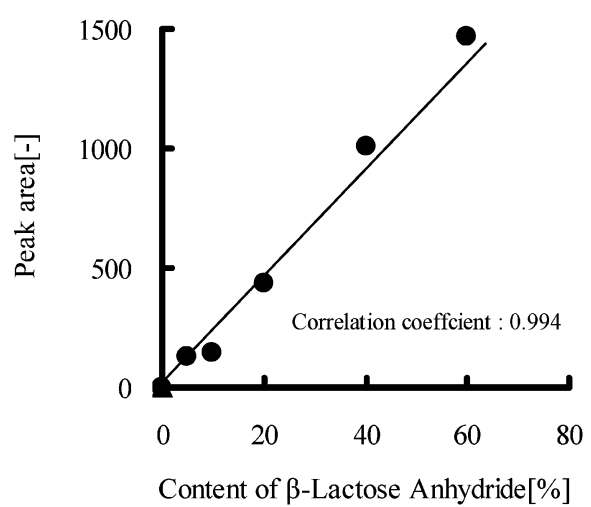

Fig. 4. Correlation between Crystal Lactose Contents in Physical Mixture and Peak Area of Powder X-ray Diffraction 
も，粒子同士の架橋の程度と Fig. 5 の硬度の推移 との相関がみられた．特に，加湿が進み硬度が低下 する原因について，架橋の程度が関係することがわ かった.

4. 加湿時間と成形体表面の結晶乳糖量との関係 前述の回折角 $2 \theta=10.5^{\circ}$ ( $\beta$ 乳糖)， $2 \theta=12.5^{\circ}(\alpha$ 乳糖）でのピーク面積を求める方法により，各加湿 時間での結晶乳糖の生成量を測定した結果を Fig. 7

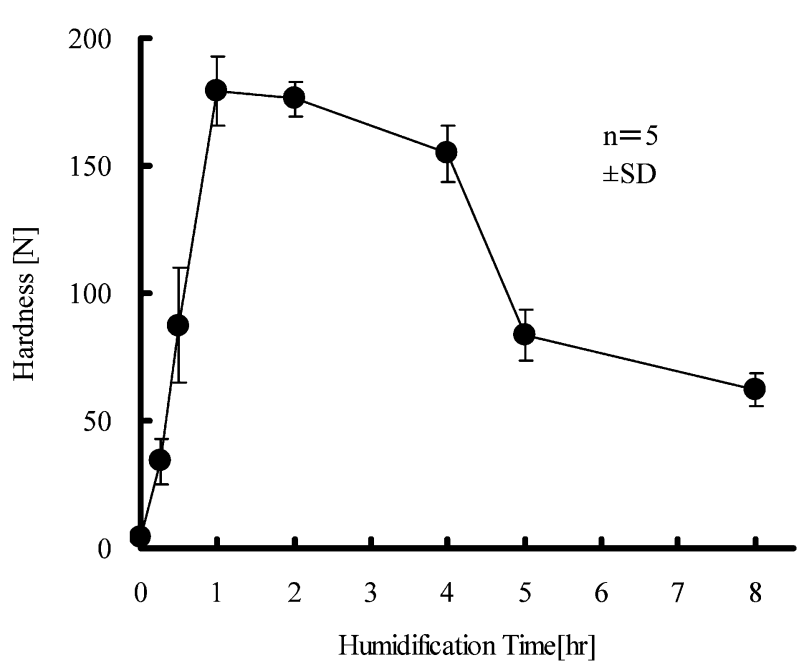

Fig. 5. Effect of Humidification Time on Hardness of Compressed Baby Milk Powder
に示した。加湿時間に伴い非結晶乳糖からの結晶化 が進行し，1 時間で乳糖の全量が結晶化した。 その 後，結晶乳糖の量の変化はみられなかった。なお， 粉ミルク中の乳糖含量は $51 \%$ であ.

5. 加湿乾燥による固形化粉ミルク表面の結晶乳 糖の転移と硬度との関係＼cjkstart加湿時間による $\alpha$ 乳 糖と $\beta$ 乳糖の含有量の変化を Fig. 8 に示した. 加湿 前の成形体の乳糖は非結晶であり結晶はみられない

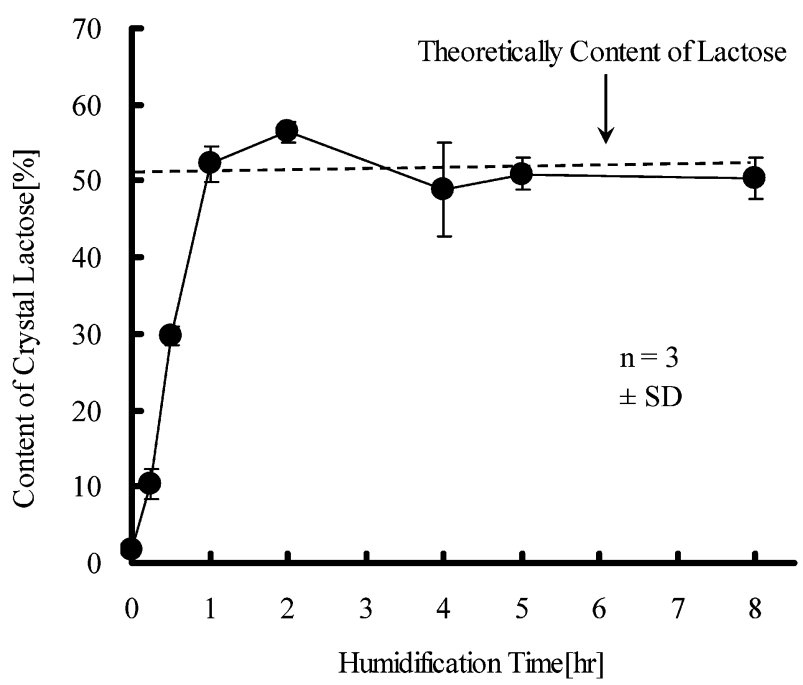

Fig. 7. Effect of Humidification Time on Total Amount of Crystal Lactose of Compressed Baby Milk Powder
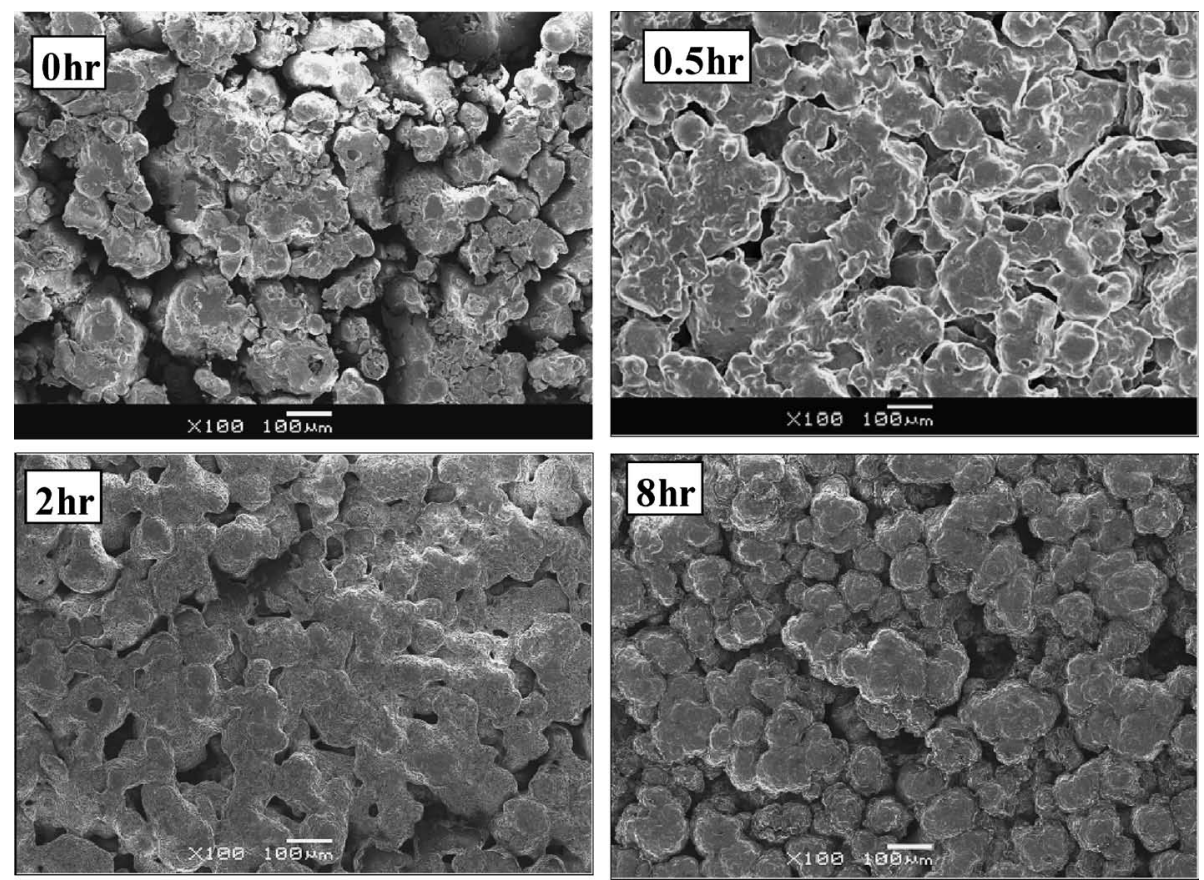

Fig. 6. Scanning Electron Micrographs of Surface of Compressed Baby Milk Powder $(\times 100)$ Humdification Time: $0 \mathrm{~h}, 0.5 \mathrm{~h}, 2 \mathrm{~h}, 8 \mathrm{~h}$. 


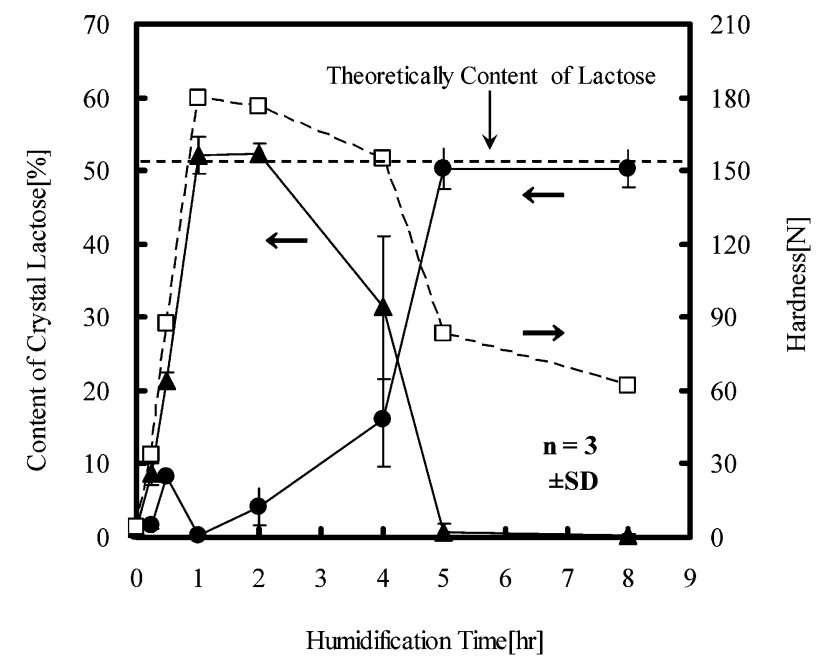

Fig. 8. Effect of Humidification Time on Crystalline Metastasis of Lactose of Compressed Baby Milk Powder Crystal form: $\boldsymbol{\ominus}, \alpha ; \boldsymbol{\Lambda}, \beta$. Hardness: $\square$.

が，加湿乾燥すると加湿の初期では $\beta$ 乳糖が増加 し，1 時間で全量が $\beta$ 乳糖となった。さらに加湿が 進むと $\beta$ 乳糖が減少し，その分 $\alpha$ 乳糖が増大し， 最終的には全量が $\alpha$ 乳糖となつた。これは，溶解 度の違い（ $\beta$ 乳糖が $\alpha$ 乳糖よりも溶解度は高い）に 起因していると考えられ，粉ミルク中で非結晶乳糖 から $\beta$ 乳糖へ転移し，さらに加湿が進むと $\beta$ 乳糖 から $\alpha$ 乳糖への転移が起こることが確認できた。

一方，硬度は乳糖の転移と相関性がみられた。す なわち，硬度の増大と非結晶乳糖から $\beta$ 乳糖への 結晶化と相関しており, 硬度の低下と $\beta$ 乳糖の減 少， $\alpha$ 乳糖の増加が相関していた。この乳糖の転移 の挙動と Fig. 6 の SEM 観察での粒子間の架橋との 間に相関性がみられたことから，非結晶乳糖が $\beta$ 乳糖へ転移し固体架橋が形成され，さらに加湿する と $\alpha$ 乳糖へと転移し固体架橋部が収縮して, 架橋 は破断されるため加湿乾燥後の成形体の硬度が低下 したものと推察した.

\section{結論}

前報9)で市販の粉ミルクを低圧縮力で圧縮成形 し，加湿乾燥処理で成形体の粒子間で架橋を形成 し，硬度が増大することを報告した。本研究では，
SEM 観察で加湿乾燥処理による成形体表面の変化 を調べるとともに，粉末 X 線回折法で粉ミルクの 主成分である乳糖の結晶性と硬度との関係について 調べた.

結果から，他成分の影響の少ない低角側で，結晶 乳糖固有の回折角のピークを見い出し，ピーク面積 と乳糖含量との間に直線性がみられたことから，成 形体表面の結晶乳糖の含有量の測定に用いた。加湿 乾燥処理で成形体表面の粒子同士の架橋が増加し, 硬度は増大した。また，非結晶乳糖が $\beta$ 乳糖へと 転移して硬度は増加し，さらに加湿すると $\alpha$ 乳糖 へと転移して硬度は減少した。このことから，粉ミ ルクの圧縮成形体を適度に加湿したのち，乾燥する 処理により，比較的疎な構造を持った成形体にある 程度の硬度を付与できることが示唆された。

\section{REFERENCES}

1) Vromans H., Bolhuis G. K., Lerk C. F., Kussendrager K. D., Bosch H., Acta Pharm. Suec., 23, 231-240 (1986).

2) Sugimoto M., Matsubara K., Koida Y., Kobayashi M., Pharm. Dev. Tech., 6, 487-493 (2001).

3) Taisho Pharmaceutical Co., Ltd., Jpn. Patent, Tokkyo Koho 4196417 (2008).

4) Kojima H., Sako K., Foods Food Ingredients J. Jpn., 210, 391-401 (2005) .

5) Meiji Dairies Corporation, Jpn. Patent, Tokkyo Koho 4062357 (2008).

6) Meiji Dairies Corporation, Jpn. Patent, Kohyo Koho 2009-521906 (2009).

7) Meiji Dairies Corporation, Kokusaikoukai Koho WO2011/158480 (2011).

8) Toyoda I., Shibata M., Kagaku to Seibutsu, 47, 506-510 (2009).

9) Shibata M., Otsubo K., Nakane S., Niwa T., Danjo K., Yakugaku Zasshi, 131, 1503-1507 (2011).

10) Ezaki S., Sugiyama M., Nihonengakukaishi, 14(4), 199-211 (1960).

11) Coble R. L., J. Am. Ceram. Soc., 56, 461-466 (1973). 